\title{
Enhancing Reading Ability of Non-English Majors With Metacognitive Strategies in After-Class Reading
}

\begin{abstract}
WANG Juan
Ningbo Dahongying University, Ningbo, China

Reading is a significant component of English learning. Since Flavell defined metacognition originally used in the field of psychology, lots of linguists and language educators home and abroad have introduced the term into language teaching and learning study. In this thesis, two classes from the Management and Finance department in Dahongying University are chosen as the experimental subjects. The result furthermore demonstrated that the usage of metacognitive strategies in after-class reading is beneficial for students to establish the good reading habits so that they can absorb more knowledge and information than before. Particularly, the students can make evaluation on whether they make progress or not in English study with the assistance of self-evaluation strategy.

Keywords: after-class reading, metacognitive strategy, self-evaluation, self- monitoring
\end{abstract}

\section{Introduction}

Reading is regarded as a cognitive process based on readers' experience, knowledge, mental and psychological activities. Since Flavell (1976) proposed the concept of metacognition which is described as "second-order cognitions: thoughts about thoughts, knowledge about knowledge, or reflections about actions" (Weinert, 1987). Metacognition has become the trend in cognitive and educational psychology. Consequently, metacongnitive strategies play a dominant role in strategy teaching, which can help readers to monitor, regulate, and evaluate other reading strategies in the reading process.

The empirical research focuses on the usage of metacognitive strategies in after-class reading with the aim of raising English ability of non-English majors. Theoretically, through a period of training, the students are anticipated to have the awareness of using metacognitive strategies automatically and foster their capacity of autonomous learning which is beneficial for their future English. The research has been given the hope of enriching the database of matecognitive strategy study and being of some help to other instructor to promote more reading programs and pedagogies in teaching English reading.

\section{Methodology}

\section{Participants}

In the research, the participants are two classes of grade one from Economy and Management department in Dahongying University, who are taught by the same English teacher. There are 42 students in each class. The

WANG Juan, lecturer, master, College of Humanity, Ningbo Dahongying University. 
mean score of their college entrance exam is below 86 and the full mark is 150. From the score, we can see most of the students' English are not so good resulted from diverse factors. One class is considered as experimental class and the other one is control class.

\section{Instrument}

Metacognitive strategy questionnaire. The questionnaire was designed and revised by the author based on O'Malley and Chamot's (1990) and Oxford's (1990) theory about classification of metacognitive strategies. There are 25 items in the questionnaire which are divided into three categories: planning, self-monitoring, and self-evaluating. The author subcategorizes self-monitoring strategy into three subcategories which are selective attention, self-management, and self-regulation.

For each question, the students involved should choose the suitable answer according to their performance in English reading. Below each question, five answers which represent different grades are included. The student who chooses "one" as his answer will get one score. One represents "never do like this". Two represents “occasionally do like this”. Three represents "sometimes do like this”. Four represents "often do like this”. Five represents "always do like this". From left to right, the frequency is higher than the former one. After finishing the questionnaire students can get the result by themselves. Generally speaking, the more score they get, the more frequent they use the metacognitive strategies in their reading.

Standard reading comprehensive tests. Two tests are in the research. One is pre-training test and the other one is post-training test from which the author can analyze the results to dig out the impact of metacognitive strategies on students' reading competence. Each test consists of three passages of reading comprehension randomly chosen from CET4 (College English Test) exams. Each test in this research contains 15 multiple choices.

After-class reading materials. Compared with in-class reading, after-class reading is more flexible without the limits of time, place, and content. They can read for pleasure or they can read for information. In China, students read newspapers, magazines, material prepared for exam, novels, some specialized English materials. According to Krashen's (1985) input theory, comprehensive input plays an important role in promoting students' language competence. The reading material should be at an acceptable higher level than students' language competence. The author chooses College English Extensive Reading, Book I (WU, 2008) as the after-class reading material used in the research. Each of the passage contains more than 1,000 English words.

\section{Procedures}

The whole research lasted for three months. And the whole procedure can be divided into three phases: preexperiment, while-experiment, and post-experiment.

Pre-experiment. Experiment class is going to receive metacognitive strategy training and is required to use the strategy in their after-class reading. Control class is not going to be taught metacognitive strategy and is not required to use metacognitive strategy in their after-class reading. Both of the experiment class and control class have to fill out a questionnaire about metacognitive strategy in reading and the current situation of students' after-class reading. A pre-test is carried out to both of the classes. Students are asked to finish three passages of reading comprehension to check whether the two classes are at the same level of reading competence.

While-experiment. In the second phase, both of the classes are asked to read the College English 
Extensive Reading after class. They are asked to read at least one passage every two weeks. The control group will not receive any training about metacognitive strategies. In after-class reading, the students in control class are just required to finish the exercise in the book and they are not required to use any strategies during the reading process. Whether using the reading strategies or not depends on their own reading habit and the discussion is not compulsive. On the contrary, besides receiving some reading strategies such as predicting, guessing the meaning of the unknown words, finding the topic sentence, etc., the experimental class will be taught metacoginitive strategies and they are required to use the metacognitive strategies in their after-class reading. They must write down what they did and what strategies they used in the reading according to the teacher's model and hand in so that teacher can monitor and facilitate to their usage of metacognitive strategies in after-class reading. Teacher can make a revision of teaching metacognitive strategy according to their notes. They must work in groups to talk about their gains, loss and help each other to solve the problems they encountered in their reading.

Post-experiment. In the third phase, after three months of training, both experimental class and control class are asked to participate in the post-test which is composed of three passages of reading comprehension from CET4 test to confirm the coefficient of difficulty is approximately the same between pre-test and post-test. The author collects the data and compares the differences in scores between the two classes. And also the respective differences between the result in pre-test and the result in post-test of each class draw attention. The data will be analyzed from the perspective of descriptive analysis and correlation statistical analysis. SPSS 13.0 will be used in post-test.

\section{Data Analysis and Discussion}

In this part, the author is going to analyze the data collected from the pre-questionnaire, pre-test, post-questionnaire, and post-test. The data will be compared to testify whether the frequency of the usage of metacognitive strategy in after-class reading is improved or not through the training, whether the reading ability is improved or not and the relationship between students' reading ability and metacognitive strategy in after-class reading. The effect of metacognitive strategy will be evaluated on the basis of the data. In order to make the data analysis scientifically, the data will be calculated by SPSS 13.0 which is widely used in the statistics analysis in social science.

\section{Statistics Analysis of Pre-test}

Before the metacognitive strategy training, both of the control class and experimental class took part in pre-test which was composed of three passages in which 15 multiple choices were included. In order to make the result easy to be calculated, the full mark of the test is 15 . The aim of the pre-test is to check whether the two classes are at the same level of reading capability or not. The data collected in the test will be analyzed based on the independent sample test and descriptive analysis.

Table 1

Statistics Analysis in Pre-test

\begin{tabular}{llllllll}
\hline Class & NO. & Max & Mini & Mean & Std. D & Sig. & $t$ \\
\hline Experimental class & 42 & 14 & 3 & 7.2143 & 2.27966 & 0.585 & 0.548 \\
Control class & 42 & 12 & 3 & 7.50000 & 2.49145 & & \\
\hline
\end{tabular}


From Table 1, we can see that the students' average reading ability in both of the classes is relatively low since the mean scores in both classes are no more than 7.5 which is the half of the total score. From mean score we can see that there is no big difference of reading ability in both of the classes. From Std. D $(2.491>2.279)$, we can see that the differences of students' reading ability in control class is a little bit wider than that in experimental class. The Sig. is 0.585 which is above 0.05 . That is to say, $\mathrm{P}>0.05$ in pre-test, which implies that there is no significant difference in students' reading ability in both classes. They are at the same level.

\section{Data Analysis in Pre-questionnaire}

In pre-questionnaire, there are 25 items which are categorized by the author in the above table. There are 42 students in each class involved in filling in the questionnaire. The objective of the questionnaire is to overview the usage of metacognitive strategy of non-English majors. The author is going to calculate the numbers of students who choose the same answer and compare the data of control class and experimental class to see whether the two classes have significant difference in using the strategies or not. The data in pre-questionnaire will be analyzed on the independent sample test in SPSS 13.0.

The data will be analyzed according to different strategies. They are planning, monitoring, and evaluation. Compared the mean score of the two groups, in questions 15 ( $\mathrm{P}=0.008), 14(\mathrm{P}=0.099)$, and $10(\mathrm{P}=0.046)$, we can see there is significant difference in the mean score in Q15, Q14, and Q10. In the most questions $(\mathrm{P}>0.05)$ we can see there are no big differences between the two classes of using metacognitive strategies. And for most questions, the mean score in control class is a little bit higher than that in experimental group. From Q10, we can see more students in experimental group frequently regulate the prior prediction according to the content of the passage. In Q14, more students in control class will seldom or sometimes ask themselves questions to deepen the understanding of the passage. In Q15, more students in experimental group use different reading strategies than control group according to different requirements of the passage. Overall, some of the students lack metacognitive strategies. Generally speaking, both of the two classes do not do well in evaluation which is considered as the essential characteristic used to distinguish metacognitive strategies from other strategies. From the answers of Q22, Q23, and Q24, the students in control class do better than experimental class on the usage of monitoring strategies. In experimental class, nearly no one often or always check whether they have reached the subjective of reading. No one make evaluation on the strategies used by them. No one reflect their reading method and write down their response. In control class, more students often or always use the above strategies. In planning, we can see both of the two classes have low awareness of after-class reading. Since half of each class never or seldom do the after-class reading. In experimental group, five students often or always do the after-class reading and five students often or always make plan of the reading. In control group, only one student always does after-class reading and one always makes plan of the reading. The reason is that the English teaching in high school is exam-oriented and much more attention has been focused on doing exercise and finishing the exam papers all the time. Most students hold the view that English learning should be taught in class rather than learnt both in class and after class. Before training, most of them can make the plan of using different reading speeds according to different requirements of reading materials. In monitoring, comparatively speaking, we can see students are poor in using strategy of self-management such as pick out the good sentence and new words, etc.. Most students are used to writing down the isolated grammar knowledge or phrases based 
on teacher's requirement rather than automatically taking notes when they are doing reading by themselves. Thus, the teacher is going to train students how to use metacognitive strategies and the strategy of evaluation will be paid more attention.

\section{Statistics Analysis in Post-test}

At the end of the research, both of the experimental class and control class are asked to finish the reading test. In order to check whether there is significant difference between experimental group and control group, the author is going to statistically analyze the result of the reading comprehension test by SPSS 13.0. Like pre-test, three passages are included and the full mark is 15.

Table 2

Statistical Analysis of Post-test

\begin{tabular}{llllllll}
\hline Class & NO. & Max & Mini & Mean & Std. D & Sig. & t \\
\hline Experimental class & 42 & 14 & 4 & 9.1905 & 2.39143 & 0.046 & 2.027 \\
Control class & 42 & 14 & 4 & 8.2143 & 2.00652 & & \\
\hline
\end{tabular}

From the data in Table 2, we can see that in both experimental class and control class, the maximum score and minimum score are respective 14 and 4 . In experimental class, the mean score is 9.1905, which is higher than the mean score in control class whose mean score is 8.2143. From Std. D $(2.39143>2.00652)$ it can be concluded that the differences of students' reading ability in experimental class is wider than that of control class. The Sig. is 0.046 ( $\mathrm{P}<0.05$ ), which means there is a significant differences between the students' reading ability in experimental class and that in control class.

\section{Data Analysis of Post-questionnaire}

In order to make sure whether there is a big difference between experimental class and control class in using metacognitive strategies after the training. Both of the classes are required to fill in the post-questionnaire and all the questions are about metacognitive strategies from pre-questionnaire. All the data in post-questionnaire will be analyzed on the basis of independent sample test in SPSS 13.0.

From the data, we can see awareness on metacognitive strategy in both classes have improved. We can see in eight questions ( $\mathrm{P}>0.05$ ), there is no significant difference, but the mean score of each question in experimental group is higher than control group. And for the rest of the questions, there is a significant difference $(\mathrm{P}<0.05)$ between experimental class and control class. It is apparent that, the awareness of using metacognitive strategies in experimental class is higher than the control class. The mean scores of evaluation strategy in both classes are comparatively lower than the mean score of other strategies, so that the awareness of using the evaluation strategy needs to be improved.

\section{Discussion}

In pre-test, we can see there is no significant difference between the experimental class and control class. From their mean score, we can see the reading ability of the two classes does not meet the standard required by CET4. In post-test, the mean score of each class have increased. The mean score of experimental class is higher than control class and there is a significant difference between the two classes. From this, we can see the reading ability in experimental class has greatly improved. Training plays a positive role in improving students' reading ability. 
In pre-questionnaire, both of the experimental class and control class have a low level of using metacognitive strategies, especially in using the strategy of evaluation. Comparing the result of pre-questionnaire and post questionnaire, we can see the frequency of using metacognitive strategies has greatly improved in experimental class, which has a great consistency in what they wrote in their note-taking. In post-questionnaire, there is significant difference in using metacognitive strategies between the two classes, especially in using evaluation stratege.

From the two perspectives above, it is proven that the metacognitive strategies in after-class reading are positive in improving the students' reading ability.

\section{Conclusion}

In this part, the author is trying to summarize the findings of the research and reveal the implication for English teaching in after-class reading, which is the terminal objective of the research. At the same time, there are some questions unsolved because of the various reasons which will be presented in this chapter and used to future study.

\section{Findings}

The statistic analysis and subjective analysis in the research have presented the progress in students' reading ability through training and some findings are as following: First, the metacognitive strategy in after-class reading is helpful to raise the learners' reading competence. Second, the training is helpful for students to establish a good habit in after-class reading and they can use some of the metacognitive strategies automatically in their reading, such as planning, selective attention, and evaluation. Third, metacongitive strategy can help students to enhance their reading efficiency in after-class reading so that students will not feel intimidated when they are faced with the long passage and they will get more information from after-class reading, thus their interest in reading has been aroused with the assistance of using metacognitive strategy.

\section{Pedagogic Implications}

The correlation between metacognitive strategies and reading ability has been proven in the research. The findings give some implications for college English teaching for non-English majors:

First, for non-English majors, their English learning should not be limited within the class learning. Doing some after-class reading is essential for them not only because they can acquire some English knowledge such as enlarging the vocabulary, grasping the useful sentence, accumulating some reading skills but also because they get the connotation of the passage, which is beneficial for their future English study.

Second, for non-English majors, the after-class reading should be undergone with the supervision and guidance of teachers. Since it will take a much longer time for non-English majors to realize the importance of after-class leaning and reap the benefits of after-class reading. It is very easy for them to give up after-class reading without the supervision of teachers.

Third, the teacher should focus on helping students to get into the habit of using metacognitive strategies automatically. Since metacoginitve strategy is considered as the efficient tool of reading, which can improve the reading efficiency. The teachers should teach students what the metacongnitve strategies are and how to use them in class reading as well as after-class reading. The teacher should require students to do plenty of metacognitive 
strategy practice until the frame of metacoginitive strategies is formed. Therefore, the students will use the strategies automatically.

Some limitations exist in the present study, but the author hoped that the research will be helpful for the further study in college English teaching and learning.

\section{References}

Baker, L., \& Brown, A. (1984). Metacognitive skills and reading. In Handbook of reading research (pp. 353-394). New York: Longman.

Bell, T. (1998). Extensive reading: Why? and how?. The Internet TESL Journal, IV(12), 12.

Carrell, P. L., Pharis, B. G., \& Liberto, J. C. (1989). Metacognitive strategy training for ESL reading. TESOL Quarterly, 23(4), 647-684.

Ellis, R. (1997). Second language acquisition. New York: Oxford University Press.

Flavell, J. H. (1976). Metacognitive aspects of problem of solving. In The nature of intelligence (pp. 231-235). Hillsdale, NJ: Erlbaum.

Flavell, J. H. (1987). Speculations about the nature and development of metacognition. Mahwah, New Jersey: Lawrence Erlbaum Associates.

Hartman, H. J. (1998). Metacognition in teaching and learning: An introduction. Instructional Science, 26, 268-286.

Hinkel, E. (2005). Handbook of research in second language teaching and learning. Mahwah, New Jersey: Lawrence Erlbaum Associates.

Johnson, K., \& Johnson, H. (1998). Encyclopedic dictionary of applied linguistics: A handbook for language teaching (p. 333). New York: Blackwell Publishers Ltd..

Krashen, S. (1985). The input hypothesis: Issues and implication. New York: Longman.

O’Malley, J. M., \& Chamot, A. (1990). Learning strategies in second language acquisition. Cambridge: Cambridge University Press.

Oxford, R. (1990). Language learning strategies: What every teacher should know. New York: Newbury House Publishers.

Susser, B., \& Robb, T. N. (1990). EFL extensive reading instruction: Research and procedure. JALT Journal, 12(2), 161-185.

Weinert, F. (1987). Metacognition and motivation as determinants of effective learning and understanding. In Metacognition, motivation, and understanding. Hillsdale, NJ: Erlbaum.

WU, G. L. (2008). College English extensive reading. Zhejiang: Zhejiang University Press. 